\title{
Effects of Different Levels of NPK and Molybdenum on Soil Physico - Chemical Properties of Black Gram (Vigna mungo L.) Var. Shekhar-2
}

\author{
Amrita Markam*, Narendra Swaroop, Tarence Thomas and Soman Singh Dhruw \\ Department of soil science and Agricultural Chemistry, Sam Higginbottom University of \\ Agriculture, Technology and Sciences, Allahabad, 211007 (U.P.) India \\ *Corresponding author
}

\section{A B S T R A C T}

\begin{tabular}{|l|}
\hline Ke y w or d s \\
NPK, Molybdenum, \\
Soil physico- \\
chemical properties, \\
Black gram. \\
\hline Article Info \\
\hline $\begin{array}{l}\text { Accepted: } \\
\text { 14 June } 2017 \\
\text { Available Online: } \\
\text { 10 August } 2017\end{array}$ \\
\hline
\end{tabular}

The experiment was carried out at Department Soil Science and Agricultural Chemistry research farm SHUATS, Allahabad during summer season 2016-2017. The experiment was laid out in $3 \times 3$ factorial randomized block design with three replications, consisting of nine treatments. Treatment $\mathrm{T}_{8} @\left(25: 40: 40 \mathrm{~kg} \mathrm{NPK} \mathrm{ha}^{-1}+100 \mathrm{~g}\right.$ Molybdenum ha ${ }^{-1}$ ) was to be best in data were recorded in post harvest soil as $\mathrm{pH}, \mathrm{EC}\left(\mathrm{dSm}^{-1}\right), \mathrm{O} . \mathrm{C}(\%)$, Pore space $(\%)$, Bulk density $\left(\mathrm{g} / \mathrm{cm}^{3}\right)$, particle density $\left(\mathrm{g} / \mathrm{cm}^{3}\right)$, water holding capacity $(\%)$, nitrogen $\left(\mathrm{kg} \mathrm{ha}^{-1}\right)$, phosphorus $\left(\mathrm{kg} \mathrm{ha}^{-1}\right)$, potassium $\left(\mathrm{kg} \mathrm{ha}^{-1}\right)$ and molybdenum $\left(\mathrm{g} \mathrm{ha}^{-1}\right)$ which were as $7.39,0.21,0.77,50.33,1.19,2.44,59.14,345.93,32.10,661.41,15.81$ respectively. Treatment $\mathrm{T}_{6} @\left(25: 40: 40 \mathrm{~kg} \mathrm{NPK} \mathrm{ha}^{-1}+0 \mathrm{~g}\right.$ Molybdenum ha $\left.{ }^{-1}\right)$ was to be best in pore space $(\%)$ which were as 52.00 . The treatment $\mathrm{T}_{2}$ was to be best in particle density was as $2.47\left(\mathrm{~g} / \mathrm{cm}^{3}\right)$. Soil chemical properties as available N, P, K, S, EC and O.C were found to be significant but $\mathrm{pH}$ was non-significant. Soil physical properties as bulk density $\left(\mathrm{g} / \mathrm{cm}^{3}\right)$, particle density $\left(\mathrm{g} / \mathrm{cm}^{3}\right)$, pore space $(\%)$ and water holding capacity $(\%)$ were found to be significant.

\section{Introduction}

Pulses are one of the second most important segments of Indian Agriculture after cereals as they rich in protein and play vital role in human diet. Pulses improve soil health by enriching nitrogen status, long-term fertility and sustainability of the cropping systems. It meets up to $80 \%$ of its nitrogen requirement from symbiotic nitrogen fixation from air. In India, production of pulses is around 19.3 million tonnes with a very low average productivity of $764 \mathrm{~kg} \mathrm{ha}^{-1}$. Pulses are least preferred by farmers because of high risk and less remunerative than cereals; consequently, the production of the pulses is sufficiently low. Black gram (Vigna Mungo L.), is one of the important pulses crop, grown throughout the country. Among pulses, black gram has increased from $1.87 \mathrm{~m}$ ha in $1971-72$ to 3.11 $\mathrm{m}$ ha during 2012-13 with production level of 1.90 MT (ESI 2015). This increase in production is mainly attributed to additional area brought under the crop as well as productivity gains (from 0.5 to $1.3 \mathrm{t} \mathrm{ha}^{-1}$ ). Summer cultivation in northern India and winter cultivation in rice fallows in southern and coastal areas of the country also added to additional acreage. Black grams are widely considered as an excellent source of high quality protein with good digestibility and also contain water soluble vitamins and 
minerals of dietary significance. The factors attributed for low yields of pulses in India as compared to the world productivity are nonavailability of quality seeds of improved and short duration varieties, growing of pulses under marginal and less fertile soil with low inputs and without pest and disease management, growing of pulses under moisture stress, unscientific post harvest practices and storage under unfavourable conditions. Hence, there is a scope for improving the production potential of this crop by use of organic manures, inorganic manures and biofertilizers (Shrikant Vadgave, 2010). Integrated nutrient management includes the intelligent use of organic, inorganic, and on-line biological resources so as to sustain optimum yields, improve or maintain the soil physical and chemical properties, and provide crop nutrition packages which are technically sound, economically attractive, practically feasible and environmentally safe. The existing state blanket recommendation for crops does not ensure efficient and economic use of fertilizers, as it does not take into account the fertility variations resulting in imbalanced use of fertilizer nutrients. Among the various methods of fertilizer recommendations, the soil test based fertilizer recommendations is also appropriate practices to improve yield as well as soil nutrient status (Gayathri et al., 2009). The present investigation was therefore initiated to work out the response of FYM, soil test based NPK, Sulphur and Mo along with Rhizobium on yield and yield attributes of black gram.

Urdbean [Vigna mungo (L.) Hepper] is among the major pulses grown throughout the country during both in summer and rainy season. It is a self pollinated leguminous crop containing $24 \%$ protein, $60 \%$ carbohydrate, $1.3 \%$ fat, $3.2 \%$ minerals, $0.9 \%$ fibre, $154 \mathrm{mg}$ calcium, $385 \mathrm{mg}$ phosphorus, $9.1 \mathrm{mg}$ iron and small amount of vitamin B-complex. Being a short duration crop, it fits well in various multiple and intercropping systems. After removing pods, its plant may be used as good quality green or dry fodder or green manure. Being a legume, it also enriches soil by fixing atmospheric nitrogen. Urdbean contributes about 13 per cent of total area and 10 per cent production of pulses in our country. It is grown on $3.06 \mathrm{~m}$ ha area with a production of $1.70 \mathrm{~m} \mathrm{t}$ and productivity of $555 \mathrm{~kg} \mathrm{ha}^{-1}$ in the country (DAC, 2014). This crop is extensively grown in the states of Maharashtra (23.36\%), Andhra Pradesh (18.50\%), Uttar Pradesh (12.29\%), Madhya Pradesh (11.86\%), Tamil Nadu (8.64\%) and Rajasthan (4.29\%). It can be grown on all type of soils ranging from sandy loam to heavy clay except alkaline and saline soils. However, it does well on heavier soils such as black cotton soils which retain higher moisture for longer time.

\section{Materials and Methods}

The experiment was conducted during summer season of 2016 at research field of Department of Soil Science and Agricultural Chemistry, Allahabad School of Agriculture SHUATS Allahabad. The experimental site is located in the sub-tropical region with $25^{0} 27^{1}$ $\mathrm{N}$ latitude $81^{0} 51^{1} \mathrm{E}$ longitudes and 98 meter above sea level altitudes. The experiment was laid out in a $3 \times 3 \mathrm{RBD}$ factorial design with each three levels of NPK and Molybdenum with nine treatments, each consisting of three replicates. The total number of plots was 27 Black gram (Vigna mungo L.) were sown in summer season plots of size $2 \times 2 \mathrm{~m}$ in order of Inceptisol and is alluvial in nature, both the mechanical and chemical analysis of soil was done before starting of the experiment to ascertain the initial fertility of the soil. The soil samples were randomly collected from 0 $15 \mathrm{~cm}$ depths at randomly prior to tillage operations. The treatment consisted of nine combination of inorganic source of fertilizers $\mathrm{T}_{0} @\left(0: 0: 0 \mathrm{~kg} \mathrm{NPK} \mathrm{ha}{ }^{-1}+0 \mathrm{~g} \mathrm{Mha}^{-1}\right), \mathrm{T}_{1-} @$ (0:0:0 kg NPK ha $\left.{ }^{-1}+50 \mathrm{~g} \mathrm{M} \mathrm{ha}^{-1}\right), \mathrm{T}_{2-} @$ 
(0:0:0 kg NPK ha $\left.{ }^{-1}+100 \mathrm{~g} \mathrm{M} \mathrm{ha}^{-1}\right), \mathrm{T}_{3-} @$ $\left(12.5: 20: 20\right.$ kg NPK ha $\left.{ }^{-1}+0 \mathrm{~g} \mathrm{M} \mathrm{ha}^{-1}\right), \mathrm{T}_{4} @$ (12.5:20:20 kg NPK ha $\left.{ }^{-1}+50 \mathrm{~g} \mathrm{M} \mathrm{ha}^{-1}\right), \mathrm{T}_{5-} @$ $\left(12.5: 20: 20 \mathrm{~kg} \mathrm{NPK} \mathrm{ha}^{-1}+100 \mathrm{~g} \mathrm{M} \mathrm{ha}^{-1}\right), \mathrm{T}_{6-}$ @ (25:40:40 kg NPK ha $\left.{ }^{-1}+0 \mathrm{~g} \mathrm{M} \mathrm{ha}^{-1}\right), \mathrm{T}_{7-} @$ $\left(25: 40: 40\right.$ kg NPK ha $\left.{ }^{-1}+50 \mathrm{~g} \mathrm{M} \mathrm{ha}^{-1}\right), \mathrm{T}_{8-} @$ $\left(25: 40: 40 \mathrm{~kg}\right.$ NPK ha $\left.{ }^{-1}+100 \mathrm{~g} \mathrm{M} \mathrm{ha}^{-1}\right)$. The source of NPK and Molybdenum as Urea, SSP, MOP and Sodium molybdate $\left(\mathrm{Na}_{2} \mathrm{MoO}_{4} 2 \mathrm{H}_{2} \mathrm{O}\right)$ respectively.

\section{Results and Discussion}

\section{Physical properties}

The result depicted in table 3 shows that the maximum bulk density of soil $\left(\mathrm{g} / \mathrm{cm}^{3}\right)$, was found in $\mathrm{T}_{6}$ which was 1.20 and minimum was found in $T_{7}$ which was $1.14\left(\mathrm{~g} / \mathrm{cm}^{3)}\right.$. The interaction effects of NPK and Molybdenum on bulk density $\left(\mathrm{g} / \mathrm{cm}^{3}\right)$ of soil were found significant. The results shows that the maximum particle density of soil $\left(\mathrm{g} / \mathrm{cm}^{3}\right)$, was found in $\mathrm{T}_{1}$ which was 2.51 and minimum was found in $\mathrm{T}_{0}$ which was $2.21\left(\mathrm{~g} / \mathrm{cm}^{3}\right)$. The interaction effect of NPK and Molybdenum on particle density $\left(\mathrm{g} / \mathrm{cm}^{3}\right)$ of soil was found non-significant. The results shows that the maximum pore space $(\%)$ of soil, was found in $\mathrm{T}_{4}$ which was 52.00 and minimum was found in $\mathrm{T}_{0}$ which was 47.33 The interaction effect of NPK and Sulphur on pore space (\%) of soil were found significant (Table 1).

Table.1 Physical analysis of soil

\begin{tabular}{|c|c|c|}
\hline Particulars & ethod employed & Results \\
\hline $\begin{array}{lr}\text { Sand }(\%) & \begin{array}{r}\text { Bouy } \\
\text { meth }\end{array} \\
\text { Silt }(\%) & \\
\text { Clay }(\%) & \text { Core } \\
\text { Textural class } & \text { Core } \\
\text { Bulk density }\left(\mathrm{g} / \mathrm{cm}^{3}\right) & \text { Gradu } \\
\text { Particle density }\left(\mathrm{g} / \mathrm{cm}^{3}\right) & \text { Grad } \\
\text { Pore Space }(\%) & \text { Wrader holding capacity }(\%) \text { Grad } \\
\end{array}$ & $\begin{array}{l}\text { loucous Hydrometer } \\
\text { lod Bouyoucous (1927) } \\
\text { method } \\
\text { method Muthuaval (1992) } \\
\text { lated measuring cylinder Muthuaval (1992) } \\
\text { uated measuring cylinder Muthuaval (1992) } \\
\text { luated measuring cylinder Muthuaval (1992) }\end{array}$ & $\begin{array}{c}62.71 \\
23.10 \\
14.19 \\
\text { Sandy loam } \\
1.23 \\
2.27 \\
48.53 \\
53.53 \\
\end{array}$ \\
\hline \multicolumn{3}{|c|}{ Table. 2 Chemical analysis of soil } \\
\hline Particulars & Method employed & Results \\
\hline $\mathrm{pH}(1: 2)$ & $\begin{array}{l}\text { Digital pH meter } \\
\text { (Jackson, 1958) }\end{array}$ & 7.59 \\
\hline $\mathrm{EC}\left(\mathrm{dSm}^{-1}\right)$ & $\begin{array}{l}\text { EC meter (Digital Conductivity Meter) } \\
\text { (Wilcox, 1950) }\end{array}$ & 0.17 \\
\hline Organic Carbon (\%) & (Walkley and Black's method, 1947) & 0.48 \\
\hline Available Nitrogen $\left(\mathrm{kg} \mathrm{ha}^{-1}\right)$ & $\begin{array}{l}\text { Alkaline potassium permanganate method } \\
\text { (Subbiah and Asija, 1956). }\end{array}$ & 215.23 \\
\hline Available Phosphorus $\left(\mathrm{kg} \mathrm{ha}^{-1}\right)$ & $\begin{array}{l}\text { Colorimetric method } \\
\text { (Olsen et al., 1954) }\end{array}$ & 20.33 \\
\hline Available Potassium $\left(\mathrm{kg} \mathrm{ha}^{-1}\right)$ & $\begin{array}{l}\text { Flame photometric method } \\
\text { (Toth and Prince, 1949) }\end{array}$ & 126.65 \\
\hline Available Molybdenum $\left(\mathrm{kg} \mathrm{ha}^{-1}\right)$ & $\begin{array}{l}\text { Colorimetric method } \\
\text { (C.H Williams, 1955) }\end{array}$ & 11.25 \\
\hline
\end{tabular}


Table.3 Soil properties

\begin{tabular}{|c|c|c|c|c|c|c|c|c|c|c|c|}
\hline Treatment & $\begin{array}{c}\text { pH } \\
(\mathbf{w} / \mathbf{v})\end{array}$ & $\begin{array}{c}\mathrm{EC} \\
\left(\mathrm{dSm}^{-1}\right)\end{array}$ & $\begin{array}{c}\text { Bulk } \\
\text { density } \\
\left(\mathrm{g} / \mathrm{cm}^{3}\right)\end{array}$ & $\begin{array}{l}\text { Particle } \\
\text { density } \\
\left(\mathrm{g} / \mathrm{cm}^{3}\right)\end{array}$ & $\begin{array}{l}\text { Pore } \\
\text { space } \\
(\%)\end{array}$ & $\begin{array}{c}\text { Water } \\
\text { holding } \\
\text { capacity } \\
(\%)\end{array}$ & $\begin{array}{c}\text { Organic } \\
\text { Carbon } \\
(\%)\end{array}$ & $\begin{array}{l}\text { Nitrogen } \\
\left(\mathrm{Kg} \mathrm{ha}^{-1}\right)\end{array}$ & $\begin{array}{l}\text { Phosphorus } \\
\left(\mathrm{Kg} \mathrm{ha}^{-1}\right)\end{array}$ & $\begin{array}{l}\text { Potassium } \\
\left(\mathrm{Kg} \mathrm{ha}^{-1}\right)\end{array}$ & $\begin{array}{l}\text { Molybdenum } \\
\left(\mathrm{g} \mathrm{ha}^{-1}\right)\end{array}$ \\
\hline $\mathbf{T}_{\mathbf{0}}$ & 7.00 & 0.18 & 1.17 & 2.21 & 47.33 & 56.38 & 0.40 & 272.99 & 21.15 & 173.03 & 10.70 \\
\hline $\mathbf{T}_{1}$ & 7.05 & 0.19 & 1.19 & 2.51 & 48.33 & 58.08 & 0.50 & 287.22 & 24.34 & 175.27 & 11.54 \\
\hline $\mathbf{T}_{2}$ & 7.00 & 0.19 & 1.20 & 2.47 & 49.00 & 53.64 & 0.47 & 286.82 & 28.00 & 176.73 & 12.34 \\
\hline $\mathbf{T}_{\mathbf{3}}$ & 7.05 & 0.20 & 1.18 & 2.34 & 49.00 & 51.42 & 0.53 & 272.52 & 27.96 & 179.06 & 13.16 \\
\hline $\mathbf{T}_{4}$ & 6.88 & 0.18 & 1.18 & 2.33 & 52.00 & 54.89 & 0.57 & 284.68 & 28.07 & 179.18 & 13.65 \\
\hline $\mathbf{T}_{5}$ & 7.16 & 0.18 & 1.20 & 2.33 & 48.67 & 50.37 & 0.60 & 278.35 & 29.30 & 185.35 & 12.27 \\
\hline $\mathbf{T}_{6}$ & 6.82 & 0.20 & 1.14 & 2.44 & 49.33 & 53.34 & 0.60 & 311.17 & 29.11 & 185.49 & 14.54 \\
\hline $\mathbf{T}_{7}$ & 7.41 & 0.20 & 1.16 & 2.33 & 51.67 & 54.29 & 0.70 & 335.83 & 31.10 & 199.14 & 14.48 \\
\hline $\mathbf{T}_{8}$ & 7.39 & 0.21 & 1.19 & 2.44 & 50.33 & 59.14 & 0.77 & 345.93 & 32.10 & 225.53 & 15.81 \\
\hline F-test & NS & NS & $\mathrm{S}$ & NS & $\mathrm{S}$ & $\mathrm{S}$ & $\mathrm{S}$ & NS & $\mathrm{S}$ & $\mathrm{S}$ & $\mathrm{S}$ \\
\hline S.Ed. $( \pm)$ & 0.258 & 0.011 & 0.045 & 0.165 & 0.614 & 0.729 & 0.027 & 5.251 & 1.008 & 6.380 & 0.428 \\
\hline $\begin{array}{c}\text { C.D. (at } \\
5 \%)\end{array}$ & 0.546 & 0.024 & 0.096 & 0.351 & 1.301 & 1.546 & 0.058 & 11.133 & 2.138 & 13.525 & 0.907 \\
\hline
\end{tabular}


Graph.3 Soil properties
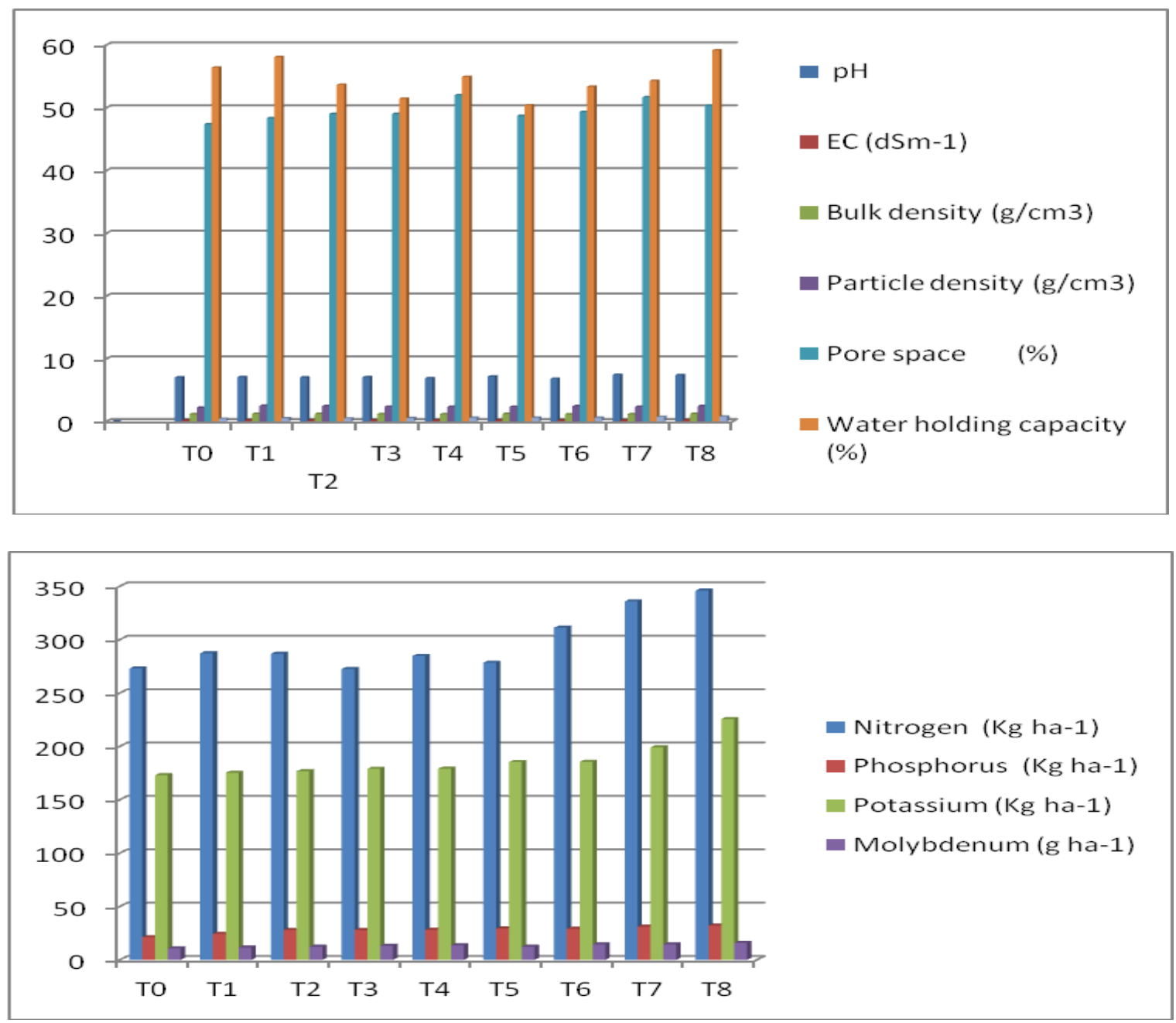

The results shows that the maximum water holding capacity (\%) of soil, was found in $\mathrm{T}_{8}$ which was 59.14 and minimum was found in $\mathrm{T}_{1}$ which was 51.42 . The interaction effect of NPK and Molybdenum on water holding capacity (\%) of soil was were found significant.

\section{Chemical properties}

Response on $\mathrm{pH}$ and EC of soil after crop harvest

The result depicted in table 3. shows that the $\mathrm{pH}$ and $\mathrm{EC}$ shows that the maximum $\mathrm{pH}$ and $\mathrm{EC}$ of soil was found in $\mathrm{T}_{7}$ which were 7.41 and 0.20 and minimum was found in $\mathrm{T}_{0}$ which were 7.00 and 0.18 . The interaction effect of NPK and Molybdenum on $\mathrm{pH}$ and EC was found non-significant (Table 2).

Response of organic carbon, available nitrogen, phosphorus, potassium and molybdenum

$\left(\mathrm{kg} \mathrm{ha}^{-1}, \mathrm{~g} \mathrm{ha}^{-1}\right)$ of soil after crop harvest

The result depicted in table 3 shows that the maximum O.C. of soil was found in $\mathrm{T}_{8}$ which was 0.77 and minimum was found in $\mathrm{T}_{0}$ which was 0.40 . The interaction effect of NPK and Molybdenum on O.C. of soil was found significant. 
The available nitrogen, phosphorus, potassium and molybdenum $\left(\mathrm{kg} \mathrm{ha}^{-1}, \mathrm{~g} \mathrm{ha}^{-1}\right)$ in soil were found maximum in $\mathrm{T}_{8}$ which were $362.80,32.10,661.41,15.81, \mathrm{~kg} \mathrm{ha}^{-1}$ and minimum was found in $\mathrm{T}_{0}$ which were $272.52, \quad 21.15, \quad 169.13, \quad 10.70, \quad \mathrm{~kg} \mathrm{ha}^{-1}$ respectively.

The interaction effect of NPK and Molybdenum on available nitrogen, potassium and molybdenum was found significant and available phosphorus, was found non-significant. Combined application of NPK and Molybdenum brings significantly increase in available Nitrogen, Potassium and molybdenum. The results are conformity with the finding of Khambalkar et al., (2012).

It is concluded that Treatment combination $\mathrm{T}_{8}$ was to be best in $\mathrm{pH}, \mathrm{EC}\left(\mathrm{dSm}^{-1}\right)$, O.C (\%), and pore space $(\%)$ bulk density $\left(\mathrm{g} / \mathrm{cm}^{3}\right)$, particle density $\left(\mathrm{g} / \mathrm{cm}^{3}\right)$,water holding capacity (\%) available nitrogen $\left(\mathrm{kg} \mathrm{ha}^{-1}\right)$, phosphorus $\left(\mathrm{kg} \mathrm{ha}^{-1}\right)$, potassium $\left(\mathrm{kg} \mathrm{ha}^{-1}\right)$ and molybdenum $\left(\mathrm{g} \mathrm{ha}^{-1}\right)$ which were as 7.39 , $0.21,0.77,50.33,1.19,2.44,59.14,345.93$, $32.10,661.41,15.81$ respectively. Treatment $\mathrm{T}_{6}$ was to be best in pore space $(\%)$ which were as 52.00 and treatment $T_{2}$ was to be best in particle density $\left(\mathrm{g} / \mathrm{cm}^{3}\right)$ as 2.47. Soil chemical properties as available $\mathrm{N}, \mathrm{K}, \mathrm{M}$ and O.C. were found to be significant but $\mathrm{pH}, \mathrm{EC}$ and available $\mathrm{P}$, were found to be nonsignificant. Soil physical properties as bulk density $\left(\mathrm{g} / \mathrm{cm}^{3}\right)$, particle density $\left(\mathrm{g} / \mathrm{cm}^{3}\right)$ and percent pore space (\%) were found to be significant

\section{Acknowledgements}

The Authors are thankful to Department of Soil Science and Agricultural Chemistry, SHUATS, Allahabad School of Agriculture, for taking their keep interest and encouragement to carry out the research work.

\section{References}

Anonymous. 2011. Ministry of Agricultural, Government of India.

Anonymous. 2014. USDA National Nutrient Database for Standard Reference Release 26 Report Date: January 23, 2014 pp 11:21 EST.

Black, C.A. 1965. Methods of soil analysis vol.2, Am. Soc. Agron., Madison, Wisconsin, U.S.A.

Bouyoucos, G.L. 1927. The hydrometer as a new method for the mechanical analysis of soils. Soil Sci., 23: 343-353.

ESI. 2015. The Economic Survey 2014-15. The Economic Survey of India, New Delhi.

Fisher, R.A. 1950. Technique of Analysis of Variance, Handbook of Agri. Statistics, B-29- 110.

Farooq, M., Wahid, A. and Siddique, H.M. 2012. Micronutrient application through seed treatments. J. Soil Sci. Plant Nutri., 12(1): $125-142$.

Jackson, M.L. 1958. Soil chemical analysis. Second edition Indian Reprint, prentice hall of India, New Dehli, pp 498.

Khan, N., Shah, Z., Ahmed, N., Ahmed, S., Mehmood, N. and Muhammad, J. 2013. Effect of integrated use of biochar, FYM and nitrogen fertilizer on soil organic fertility. Pure Appl. Bio., 2(2): 42-47.

Kumar, J. 2008. Physico-chemical properties of the soil, under the two forest plantation stands around Varanasi (U.P.), India.

Kusro, P.S., Singh, D.P., Paikra, M.S. and Kumar, D. 2014. Effect of Organic and Inorganic Additions on PhysicoChemical Properties in Vertisol. AIJRFANS, 14-124.

Meena, P.D., Chattopadhyay, C., Kumar, K., Awasthi, R.P., Singh, R., Kaur, S., Thomas, L., Goyal, P. and Chand, P. 2011. Comparative study on the effect of chemicals on Alternaria blight in 
Indian mustard - A multi-location study in India. J. Environ. Biol., 32: 375-379

Olsen, S.R., Cole, C.V., Watanhe, F.S. and Dean, L.A. 1954. Estimation of available Phosphorus in soils by extraction with sodium bicarbonate $\mathrm{U}$. S. Deptt. Agr. Circ., 939.

Prasad, J. and Likhar, C.K. 2011. Characteristics and classification of orange-growing soils developed from different parent materials in Nagpur district, Maharashtra. J. Indian Society of Soil Sci., 59: 3, 209-217. 37.

Rathore, D.S., Purohit, H.S. and Yadav, B.L. 2010. Integrated phosphorus management on yield and nutrient uptake of urdbean under rainfed conditions of southern Rajasthan, $J$. Food Legumes, 23(2): 128-137.

Subbiah, B.V. and Asija, G.L. 1956. A rapid procedure for the estimate of Available Nitrogen in Soil Current Sci., 25: 259260.

Toth, S.J. and Prince, A.L. 1949. Estimate of Cation exchange capacity and exchangeable $\mathrm{Ca}, \mathrm{K}, \mathrm{Na}, \quad$ content of soil by flame photometer technique Soil Sci., 67, pp 439-445.

Takase, M., Owusu, L.K. and Sekyere, J.D. 2011. the effects of four sources of irrigation water on soil chemical and physical properties. Asian J. Plant Sci., 10: 1, pp 92-96.18.

Verma, S. and Kumar, S.J. 2012. Impact of forest fire on physical, chemical and biological properties of soil: a review. Proceedings of the International Academy of Ecology and Environmental Sciences; 2: 3, 168-176.

Wagh, G.S., Chavhan, D. M. and Sayyed, M. R.G. 2013. Physicochemical Analysis of Soils from Eastern Part of Pune City. Universal J. Environ. Res. Technol., All Rights Reserved Eurasian Publication ( 2013eISSN 22490256.

Walkey, A. and Black, I.A. 1947. Critical examination of rapid method for determining organic carbon in soils, effect of variance in digestion conditions and of inorganic soil constituents. Soil Sci., pp. 632: 251.

Wilcox, L.V. 1950. Electrical conductivity, Am. Water Works Assoc. J., 42: 775776.

Yonter, G. and Uysal, H. 2012. The determination of the relationships between physical and chemical properties of soils to water erosion and crust strengths in Menem Plain Soils, Turkey. African J. Agri. Res., 7(2): 183193.

\section{How to cite this article:}

Amrita Markam, Narendra Swaroop, Tarence Thomas and Soman Singh Dhruw. 2017. Effects of Different Levels of NPK and Molybdenum on Soil Physico - Chemical Properties of Black Gram (Vigna mungo L.) Var. Shekhar-2. Int.J.Curr.Microbiol.App.Sci. 6(8): 1082-1088. doi: https://doi.org/10.20546/ijcmas.2017.608.134 